De Jure: Jurnal Hukum dan Syari'ah

Vol. 8, No. 1, 2016, h. 24-37

Print ISSN: 2085-1618, Online ISSN: 2528-1658

Available online at http://ejournal.uin-malang.ac.id/index.php/syariah

\title{
Manajemen Wakaf Uang di Masjid at-Taqwa Kota Batu dan Masjid Sabilillah Kota Malang dalam Perspektif Undang-Undang Nomor 41 Tahun 2004 tentang Wakaf
}

\author{
Sudirman \\ Nanda Lailatul Arofah \\ Fakultas Syariah UIN Maulana Malik Ibrahim Malang \\ sudirmansyariah@gmail.com
}

\begin{abstract}
Abstrak:
This research focuses on management of cash waqf at At-Taqwa mosque Batu and Sabilillah mosque Malang in the perspective of Act No 41 Year 2004 on Waqf. The research compared cash waqf management between two places and analyzed them using Act No 41 Year 2004 on Waqf. This research is a kind of empirical research applying descriptive qualitative approach. The findings show that those two places have both differences and similarities on their management of cash waqf. Al-Taqwa Mosque has applied cash waqf for consumptive goal for extending the mosque building while Sabilillah mosque has used cash waqf for cooperative capital. However, both institutions are aware that cash waqf should be maintained for unlimited periods of time.

Penelitian ini berfokus pada pengelolaan wakaf tunai di Masjid At-Taqwa Batu dan masjid Sabilillah Malang dalam perspektif UU No 41 Tahun 2004 tentang Wakaf. Penelitian ini membandingkan manajemen wakaf tunai antara dua tempat tersebut dan menganalisisnya dengan menggunakan Undang-Undang No 41 Tahun 2004 tentang Wakaf. Penelitian ini merupakan jenis penelitian empiris dengan pendekatan deskriptif kualitatif. Temuan penelitian ini menunjukkan bahwa kedua tempat memiliki perbedaan dan persamaan pada manajemen wakaf tunai. Masjid At-Taqwa menerapkan wakaf tunai untuk tujuan konsumtif memperluas bangunan masjid, sedangkan masjid Sabilillah menggunakan wakaf tunai untuk modal koperasi. Namun, kedua lembaga menyadari bahwa wakaf tunai harus dipertahankan untuk jangka waktu yang tak terbatas.
\end{abstract}

Kata Kunci: manajemen; wakaf uang; peraturan

\section{Pendahuluan}

Wakaf telah lama dilakukan oleh masyarakat Indonesia. Umumnya, praktik wakaf tersebut masih berupa wakaf tanah dan digunakan untuk fasilitas ibadah, semisal masjid dan mushalla, atau untuk tempat pendidikan, semacam madrasah dan pesantren. Budaya wakaf yang masih bersifat konsumtif ini perlu dirubah agar aset wakaf umat Islam bisa menjadi aset yang produktif dan memiliki dampak manfaat yang besar untuk umat Islam, khususnya di Indonesia. ${ }^{1}$ Salah satunya dengan cara memasyarakatkan wakaf uang. Wakaf uang dapat

\footnotetext{
${ }^{1}$ Supardi dan Amiruddin Teuku, Manajemen Masjid dalam Pembangunan Masyarakat,Optimalisasi dan Fungsi Masjid,(Yogyakarta: UII Press Yogyakarta,2010), h. 58.
} 
dipandang sebagai salah satu solusi yang dapat membuat wakaf menjadi lebih produktif. Uang tidak lagi dijadikan sebagai alat tukar menukar saja, akan tetapi dapat digunakan sebagai komoditas yang siap untuk memproduksi kemanfaatan yang lain. Dengan wakaf uang, banyak usaha yang bisa didanai dan berbagai fasilitas umum dapat dibangun dengan konsep menghasilkan keuntungan. Oleh karena itu, wakaf uang dapat dipandang mampu menumbuhkan perekonomian masyarakat yang berujung pada kemakmuran umat Islam.

Wakaf uang telah mendapat legitimasi di Indonesia. Berdasarkan Fatwa Majelis Ulama Indonesia (MUI) tentang wakaf uang yang ditetapkan pada tanggal 11 Mei 2002, wakaf uang sudah dapat dipraktikkan oleh masyarakat. MUI dalam penetapan kebolehan wakaf uang berlandaskan pada Al-qur'an, hadist dan pendapat ulama, seperti Imam Az-Zuhri. Terdapat tiga ulama yang mengungkapkan pendapatnya mengenai wakaf uang. Pertama, pendapat Imam al-Zuhri yang menyatakan bahwa hukum wakaf dinar adalah boleh. Kedua, pendapat ulama Hanafiyah yang membolehkan wakaf dinar/dirham atas dasar istihsan bi al-'urf. Ketiga, pendapat sebagian ulama madzhab Syafi'iyah yang diceritakan oleh Abu Tsaur tentang kebolehan wakaf dinar dan dirham. ${ }^{2}$ Keberadaan wakaf uang di Indonesia telah direspon dan diakomodasi oleh pemerintah Indonesia dalam bentuk produk hukum.Produk hukum tersebut antara lain adalah Undang-Undang Nomor 41 Tahun 2004 tentang Wakaf (selanjutnya akan disebut Undang-Undang Wakaf). Undang-Undang ini disempurnakan dengan diterbitkannya Peraturan Pemerintah Nomor 42 Tahun 2006 tentang Pelaksanaan Undang-Undang Nomor 41 Tahun 2004 tentang Wakaf. Aturan tersebut merupakan hukum positif yang berlaku di Indonesia. Lebih lanjut untuk melihat praktik wakaf uang di masyarakat, artikel ini mengungkap dua institusi yang telah mengelola wakaf uang. Lembaga tersebut adalah Masjid At-Taqwa Kota Batu yang berada di Jalan Diponegoro nomor 60 Kota Batu dan Masjid Sabilillah yang terletak di Jalan Jendral A. Yani No. 15 Kota Malang.Pengelolaan wakaf uang sudah mereka lakukan akan dianalisis dengan menggunakan Undang-Undang Wakaf.

\section{Pengertian Wakaf}

Wakaf secara bahasa berasal dari bahasa Arab, yakni waqafa-yaqifu yang artinya berhenti, lawan dari kata istamarra. ${ }^{3}$ Hans Wehr mengartikan waqafa sebagai to come to a standstill atau to come to stop. ${ }^{4}$ Kata wakaf sering disamakan dengan al-tahbis atau al-tasbil yang bermakna al-habs 'an tasharruf, yakni mencegah dari mengelola. ${ }^{5}$ Dalam literatur bahasa Inggris, wakaf biasa disebut sebagai endowment, endowment fund, atau unalienable property. ${ }^{6}$ Adapun secara istilah, wakaf menurut Abū Ḥanifah adalah menahan harta di bawah naungan pemiliknya disertai pemberian manfaat sebagai sedekah (habs al-'aini 'alā milk al-wāqif wa tasadduq bi al-manfa' $a h) .{ }^{7}$ Kemudian, menurut Jumhur, wakaf adalah menahan harta yang memungkinkan untuk mengambil manfaat dengan tetapnya harta tersebut serta memutus pengelolaan dari wakif dan selainnya dengan tujuan mendekatkan diri kepada Allah (habs māl yumkinu al- 'intifá' bihì, ma'à baqā' 'ainihi, bi qat' 'i at-tasarruf min al-wāqif wa gairihi, taqarruban ilā Allāh). ${ }^{8}$ Namun, menurut al-Kabisi, ${ }^{9}$ definisi yang lebih singkat namun padat

\footnotetext{
${ }^{2}$ Jaih Mubarok, Wakaf Produktif, (Bandung: Simbiosa Rekatama Media, 2008), h.126.

${ }^{3}$ Ahmad Warson, al-Munawwir, Kamus Arab-Indonesia, t.tp.: t.p., 1984), h. 1683.

${ }^{4}$ Hans Wehr, Arabic-English Dictionary, the Hans Wehr Dictionary of Modern Written Arabic, (Urbana: Spoken language Services, Hans, 1994), h. 1280.

${ }^{5}$ Wahbah az-Zuhaili al-Fiqh al-Islami wa Adillatuh, (Beirut: Dār al-Fikr, t.th.)h. 7599.

${ }^{6}$ Hans Wehr, Arabic-English Dictionary, h. 1280.

${ }^{7}$ Alauddin Muhammad bin 'ATi al-Hafsaki, ad-Dur al-Mukhtār, t.tp.: t.p., t.th.) v. IV, h. 532.

${ }^{8}$ Wahbah az-Zuhaili, al-Fiqh al-Islämi ..., h. 7601.

${ }^{9}$ Muhammad Abid Abdullah al-Kabisi, Hukum Wakaf, diterjemahkan oleh Ahrul Sani Fathurrohman (et.al.), Jakarta, IIMaN Press, 2004), h. 61.
} 
(jāmi ' $\left.m \overline{a n} i^{\circ}\right)$ adalah definisi Ibn Qudāmah ${ }^{10}$ yang mengadopsi langsung dari potongan hadis Rasulullah, yang berbunyi 'menahan asal dan mengalirkan hasilnya' (in syi'ta habasta așlahā fa tasaddaq bihă). Hadis tersebut secara jelas dimuat antara lain dalam sunan at-Turmużi ${ }^{11}$ dan Sunan Ibn Mājah. ${ }^{12}$

Selanjutnya, dalam Undang-Undang Nomor 41 Tahun 2004, wakaf diartikan sebagai "perbuatan hukum wakif untuk memisahkan dan/atau menyerahkan sebagian harta benda miliknya untuk dimanfaatkan selamanya atau untuk jangka waktu tertentu sesuai dengan kepentingannya guna keperluan ibadah dan/atau kesejahteraan umum menurut syariah." Dengan pesatnya perkembangan zaman, wakaf tidak lagi hanya diasosiasikan pada obyek wakaf berupa tanah, ${ }^{13}$ akan tetapi sudah merambah kepada wakaf bentuk lain, seperti benda bergerak berupa uang. Di Indonesia, beberapa jenis wakaf baru telah diakomodasi oleh Undang-Undang Nomor 41 Tahun 2004 tentang Wakaf. Hal ini merupakan bentuk penyempurnaan konsep wakaf yang terdapat dalam Kompilasi Hukum Islam. ${ }^{14}$ Wakaf dalam Instruksi Presiden Nomor 1 Tahun 1991 tersebut dimaknai sebagai "perbuatan hukum seseorang atau kelompok orang atau badan hukum yang memisahkan sebagian dari benda miliknya atau melembagakannya untuk selama-lamanya guna kepentingan ibadat atau keperluan umum lainnya sesuai dengan ajaran Islam." Perbedaan mendasar dari dua definisi ini adalah bahwa wakaf pada masa kini tidak lagi selalu identik dengan pelembagaan yang bersifat abadi namun bisa juga untuk jangka tertentu. Dari beberapa definisi wakaf di atas, dapat disimpulkan bahwa wakaf bertujuan untuk memberikan manfaat atau faedah harta yang diwakafkan kepada orang yang berhak dan dipergunakan sesuai dengan ajaran Islam. Hal ini sesuai dengan fungsi wakaf yang disebutkan pasal 5 UU Wakaf yang menyatakan wakaf berfungsi untuk mewujudkan potensi dan manfaat ekonomis harta benda wakaf untuk kepentingan ibadah dan untuk memajukan kesejahteraan umum.

\section{Pengertian Wakaf Uang}

Wakaf uang merupakan terjemahan langsung dari istilah Cash Waqf yang populer di Bangladesh, tempat A. Mannan menggagas idenya. ${ }^{15}$ Dalam beberapa literatur lain, Cash Waqf juga dimaknai sebagai wakaf tunai. Hanya saja, makna tunai ini sering disalahartikan sebagai lawan kata dari kredit, sehingga pemaknaan Cash Waqf sebagai wakaf tunai menjadi kurang pas. Untuk itu, dalam tulisan ini, Cash Waqf diterjemahkan sebagai wakaf uang. Selanjutnya, wakaf uang dalam definisi Departemen Agama adalah wakaf yang dilakukan seseorang, kelompok orang, dan lembaga atau badan hukum dalam bentuk uang. ${ }^{16}$ Dengan demikian, wakaf uang merupakan salah satu bentuk wakaf yang diserahkan oleh seorang wakif kepada nazhir dalam bentuk uang kontan. Hal ini selaras dengan definisi wakaf yang dikeluarkan oleh Komisi Fatwa Majelis Ulama Indonesia ${ }^{17}$ tanggal 11 Mei 2002 saat merilis fatwa tentang wakaf uang.

\footnotetext{
10، Abd ar-Rahmān bin Abū 'Umar ibn Qudāmah, asy-Syarh al-Kabïr, t.tp.: t.p., t.th.) vol. VI, h. 187.

${ }^{11}$ Muhammad bin 'Isa at-Turmużi, Sunan at-Turmużi, Kairo: Mauqi' Wizārah al-Auqāf al-Miṣriyyah, t.th), vol. V, h. 388

${ }^{12} I b n$ Mājah, Sunan Ibn Mājah (Kairo: Mauqi`Wizārah al-Auqāf al-Mișriyyah, t.th), vol. VII, h. 325.

${ }^{13}$ Data Tahun 2012, tanah wakaf di Indonesia berjumlah 3.492.045.374 $\mathrm{m}^{2} \mathrm{di} 420.003$ lokasi.

${ }^{14}$ Dalam Instruksi Presiden Nomor 1 Tahun 1991 itu, wakaf masih terbatas pada benda tidak bergerak.

${ }^{15}$ Dalam literatur berbahasa Arab, wakaf uang biasanya disebut dengan istilah waqf an-nuqūd, seperti dalam tulisan Abdullāh bin Mūsā, Waqf an-Nuqūd wa al-Aurāq al-Māliyah, 2005.

${ }^{16}$ Achmad Djunaidi dkk., Pedoman Pengelolaan Wakaf Tunai (Jakarta: Departemen Agama RI, 2007),h. 3.

${ }^{17}$ Tim Penyusun, 2003, Himpunan Fatwa Majelis Ulama Indonesia, Jakarta: Dirjen BimasIslam dan Urusan Haji Departemen Agama RI 2003), h. 85. Fatwa merupakan salah satu bentuk dari pembaharuan hukum Islam, selain penyusunan ensiklopedi fiqih, pembentukan undang-undang, kajian ilmiah dan artikel, dan putusan pengadilan,
} 


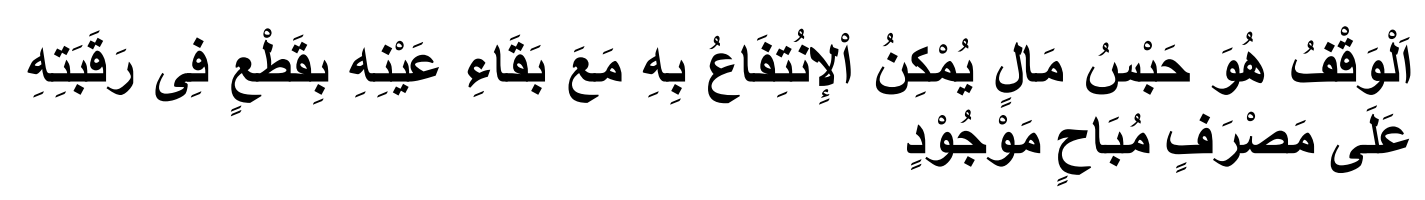

Artinya: Wakaf adalah menahan harta yang dapat dimanfaatkan tanpa lenyapnya bendanya atau pokoknya, dengan cara tidak melakukan tindakan hukum terhadap benda tersebut (menjual, memberikan, atau mewariskannya), melainkan untuk disalurkan (hasilnya) pada sesuatu yang mubah (tidak haram) yang ada.

Dalam definisi di atas, wakaf tidak lagi terbatas pada benda yang tetap wujudnya, melainkan wakaf dapat berupa benda yang tetap nilainya atau pokoknya. Uang masuk dalam kategori benda yang tetap pokoknya. Dengan demikian, definisi MUI di atas memberikan legitimasi kebolehan wakaf uang.

Adapun pengertian wakaf uang terbaru adalah versi Peraturan Menteri Agama Nomor 4 Tahun 2009 tentang Administrasi Pendaftaran Wakaf Uang, pasal 1 angka (1). Wakaf uang dalam PMA ini diartikan sebagai "perbuatan hukum wakif untuk memisahkan dan/atau menyerahkan sebagian uang miliknya untuk dimanfaatkan selamanya atau untuk jangka waktu tertentu sesuai dengan kepentingannya guna keperluan ibadah dan/atau kesejahteraan umum menurut syariah." Wakaf uang sudah dikenal sejak masa dinasti Ayyubiyah di Mesir, pada masa itu perkembangan wakaf tidak hanya barang bergerak, tetapi juga barang bergerak semisal wakaf uang. ${ }^{18}$ Wakaf uang merupakan suatu bentuk investasi uang yang diberikan kepada nadhir untuk tujuan mengharap ridha Allah semata. Bagi masyarakat Indonesia, konsep wakaf uang bisa dikatakan masih relatif baru. Hal ini bisa dilihat dari peraturanperaturan yang melandasinya, yaitu fatwa MUI yang disahkan pada tahun 2002 dan UndangUndang No. 41 Tahun 2004 tentang wakaf. ${ }^{19}$

\section{Tata Cara Wakaf Uang Menurut Undang-Undang}

Adapun wakaf yang dilakukan menggunakan benda bergerak yakni uang telah diatur dalam Undang-Undang Nomor 41 Tahun 2004 tentang Wakaf. Terdapat 4 pasal yang menerangkan wakaf berupa uang yakni pasal 28 sampai 31. Dalam pasal 28 berbunyi bahwa "wakif dapat mewakafkan benda bergerak berupa uang melalui lembaga keuangan syari'ah yang ditunjuk oleh menteri". ${ }^{20}$ Jadi seseorang yang ingin melakukan wakaf uang hendaknya ke lembaga keuangan syari'ah yang ditunjuk menteri sesuai dengan aturan tersebut. Selanjutnya untuk prosedur selanjutnya dalam melakukan wakaf uang diatur dalam pasal 29 yakni: (1) Wakaf benda bergerak berupa uang sebagaimana dimaksud dalam pasal 28 dilaksanakan oleh wakif dengan pernyataan kehendak wakif yang dilakukan secara tertulis; (2) Wakaf benda bergerak berupa uang sebagaimana dimaksud pada ayat (1) diterbitkan dalam bentuk sertifikat wakaf uang; dan (3) Sertifikat wakaf uang sebagaimana dimaksud pada ayat (2) diterbitkan dan disampaikan oleh lembaga keuangan syariah kepada wakif dan nadzir sebagai bukti penyerahan harta benda wakaf. ${ }^{21}$

Untuk lembaga keuangan syari'ah yang dimaksudkan di pasal 29 tersebut harus mendaftarkan harta benda wakaf uang tersebut kepada menteri dalam kurun waktu selambatlambatnya 7 hari. Sebagaimana yang tercantum dalam pasal 30 yakni "lembaga keuangan syari'ah atas nama nadzir mendaftarkan harta benda wakaf berupa uang kepada Menteri

\footnotetext{
Abdul Manan, Reformasi Hukum Islam di Indonesia, Tinjauan dari Aspek Metodologis, Legalisasi, dan Yurisprudensi, Jakarta: RajaGrafindo Persada, 2006),h. 185-204.

${ }^{18}$ Achmad Djunaidi dkk., Pedoman Pengelolaan, h. 12.

${ }^{19}$ Achmad Djunaidi dkk., Strategi Pengembangan, h. 8.

${ }^{20}$ Pasal 28 Undang-Undang Nomor 41 Tahun 2004 tentang Wakaf

${ }^{21}$ Pasal 29 Undang-Undang Nomor 41 Tahun 2004 tentang Wakaf
} 
selambat-lambatnya 7 (tujuh) hari kerja sejak diterbitkannya sertifikat uang". ${ }^{22}$ Kemudian untuk ketentuan lebih lanjut mengenai wakaf benda bergerak berupa uang sebagaimana dimaksud dalam pasal 28, pasal 29, dan pasal 30 diatur dengan Peraturan Pemerintah. ${ }^{23}$ Peraturan pemerintah yang mengatur tentang wakaf uang, yakni terdapat dalam pasal 22 dan 23 Undang-Undang Nomor 42 Tahun 2006 tentang pelaksanaan Undang-Undang No.41 Tahun 2004. Kedua pasal tersebut berisi sebagaimana dijelaskan berikut ini: a) Wakaf uang yang dapat diwakafkan adalah mata uang rupiah; b) Dalam hal uang yang akan diwakafkan masih dalam mata uang asing, maka harus dikonversi terlebih dahulu kedalam rupiah; c) Wakif yang akan mewakafkan uangnya diwajibkan untuk: 1) Hadir di Lembaga Keuangan Syari'ah Penerima Wakaf Uang (LKS-PWU) untuk menyatakan kehendak kehendak wakaf uangnya; 2) Menjelaskan kepemilikan dan asal-usul uang yang akan diwakafkan; 3) Menyetor secara tunai sejumlah uang ke LKs-PWU; 4) Mengisi formulir tunai pernyataan kehendak wakif yang berfungsi sebagai AIW.

Kemudian, pasal 23 menjelaskan bahwa Wakif dapat mewakafkan benda bergerak berupa uang melalui LKS yang ditunjuk oleh Menteri Agama sebagai LKS Penerima Wakaf Uang (LKS-PWU). Sampai dengan 31 desember 2015, Menteri Agama sudah menetapkan 15 Bank sebagai penerima setoram wakaf uang yaitu: Bank Muamalat Indonesia, Bank Syariah Mandiri, Bank BNI Syariah, Bank Mega Syariah, Bank DKI Syariah, Bank BTN Syariah, Bank Syariah Bukopin, BPD Jogya Syariah, BPD Kalbar Syariah, BPD Jateng Syariah, BPD Kepri Riau Syariah, BPD Jatim Syariah, BPD Sumut Syariah, Bank CIMB Niaga Syariah, dan Panin Bank Syariah. ${ }^{24}$ Secara teknis, wakaf uang atau tunai telah diatur prosedur administrasinya. Peraturan Menteri Agama Nomor 4 Tahun 2009 tentang Administrasi Pendaftaran Wakaf Uang telah ditandatangani pada tanggal 29 Juli 2009, peraturan tersebut terdiri 15 pasal.

\section{Metode Penelitian}

Jenis penelitian yang digunakan dalam penelitian ini adalah empiris (field research). Adapun datanya bersifat deskriptif (descriptive research). penelitian ini dimaksudkan untuk eksplorasi dan klarifikasi mengenai suatu fenomena atau kenyataan sosial, dengan jalan mendeskripsikan sejumlah variabel yang berkenaan dengan masalah dan unit yang diteliti. ${ }^{25}$ Pendekatan yang digunakan dalam penelitian ini adalah pendekatan kualitatif. Jadi apabila ditinjau dari data yang diperoleh maka pendekatan kualitatif ini menghasilkan data deskriptif yang berupa kata-kata tertulis atau lisan maupun prilaku seseorang yang diteliti yang dituangkan dalam bentuk paparan data. Pengumpulan data dalam penelitian ini diperoleh melalui wawancara tak berstruktur, namun wawancara ini berfokus. Wawancara berfokus biasanya terdiri dari pertanyaan yang tak mempunyai struktur tertentu, tapi selalu berpusat kepada satu pokok tertentu. ${ }^{26}$ Wawancara dilakukan kepada pengurus sekaligus panitia wakaf uang Masjid At-Taqwa Kota Batu dan pengurus Koperasi Masjid Sabilillah Kota Malang untuk memperoleh informasi mengenai pengelolaan wakaf uang di kedua tempat tersebut. Dokumentasi yang digunakan melalui dokumen. Dokumen yang digunakan dapat berupa informasi dari website, penelitian terdahulu tentang wakaf, profil, struktur organisasi, akta pendirian, catatan laporan dari Masjid Sabilillah Kota Malang dan Masjid At-Taqwa Kota Batu dan dokumen lainnya yang berhubungan dengan wakaf uang.

\footnotetext{
${ }^{22}$ Pasal 30 Undang-Undang Nomor 41 Tahun 2004 tentang Wakaf

${ }^{23}$ Pasal 31 Undang-Undang Nomor 41 Tahun 2004 tentang Wakaf

${ }^{24}$ http://bwi.or.id/index.php/in/tentangwakaf/data-wakaf/lembaga-keuangan-syariah-penerima-wakafuang.htmldiakses 8 Juni 2016

${ }^{25}$ Sanapiah Faisal. Format - Format Penelitian Sosial.(Jakarta: PT. Rajagrafindo Persada, 2005). h.20.

${ }^{26}$ Koentjaraningrat. Metode - Metode Penelitian Masyarakat, (Jakarta: PT Gramedia Pustaka Utama, 1997), h.139.
} 


\section{Pengelolaan Wakaf Uang di Masjid at-Taqwa Kota Batu}

Gerakan wakaf uang di Masjid At-Taqwa Kota Batu merupakan program yang dikonsep dan dikelola oleh pengurus masjid At-Taqwa Kota Batu.Para pengurus membentuk panitia gerakan wakaf uang agar lebih fokus dan intens dalam menjalankan program tersebut. Terdapat 8 orang panitia inti yang merupakan pengurus masjid At-Taqwa Kota Batu pula. Panitia wakaf uang masjid At-Taqwa Kota Batu melakukan berbagai cara untuk menjalankan program wakaf uang tersebut. Panitia melakukan sosialisasi wakaf uang ke khalayak umum dengan nama wakaf tunai sebagaimana termuat di banner yang telah dibuat dan dipasang di depan Masjid At-Taqwa Kota Batu. Banner tersebut mengusung jargon "Investasi Akhirat Wakaf Tunai Masjid At-Taqwa Kota Batu, Jangan Sia-siakan Sebelum Datang Masa Sulitmu". Hal tersebut dilakukan tentunya untuk menarik minat masyarakat untuk melakukan ibadah yakni wakaf uang.Selain banner, panitia juga membuat brosur wakaf uang guna disebarkan ke masyarakat. Masyarakat yang ingin mewakafkan uang atau hartanya di masjid At-Taqwa Kota Batu bisa melalui dua cara. Yang pertama yakni dengan membayar tunai dan yang kedua transfer melalui bank. Untuk yang membayar tunai bisa membayar di panitia atau takmir pada pukul $12.00 \mathrm{~s} / \mathrm{d} 20.00$ WIB (setelah sholat dhuhur/ ashar/ maghrib/ isya') di sekretariat atau masjid yang terletak di Jl. Diponegoro No. 60 Kota Batu. Sedangkan untuk yang transfer melalui bank bisa ke Bank Mandiri Syariah atas nama Masjid at-Taqwa ke nomor rekening 4443339995 atau ke bank BNI Syariah atas nama Masjid At-Taqwa ke nomor rekening 314593755. Setelah masyarakat atau wakif transfer melalui bank tersebut, wakif bisa konfirmasi SMS ke nomor $087701640565 .{ }^{27}$

Proses penerimaan wakaf uang tersebut, panitia wakaf uang di Masjid At-Taqwa Kota Batu selain menerima uang juga menerima harta berupa emas, tanah dan lain-lain. Hal tersebut dilakukan karena panitia berfikiran bahwa wakaf uang tidak hanya uang, akan tetapi bisa dengan barang lain guna mempermudah seseorang yang ingin beribadah. Konsepnya adalah mempermudah bukan untuk mempersulit. Seperti halnya yang disampaikan oleh salah satu panitia wakaf uang Masjid At-Taqwa Kota Batu berikut ini.

Tunai itu kita maknai tidak hanya uang. Bisa berupa aset, barang berharga, emas tanah yang bisa di jual.Modelnya wakif beri kuasa ke pengurus untuk mengelola tanah yang diberikan, bisa dijual atau disewakan.Tanah itu intinya untuk membantu pembebasan tanah.Wakif diberi kuasa ke takmir atau ke panitia pengurus muhammadiyah.Tidak semua wakif yang berwakaf dengan uang. Dari pengurus memberikan kefleksibelan dalam berwakaf. Jadi nggak hanya uang.Meskipun uang merupakan barang yang paling fleksibel. Misal musafir tahu ada wakaf tunai disini dan punya emas masak mau menjual ke pasar dulu baru berwakaf.Kan lama dan nggak fleksibel.Jadi bisa langsung saja diserahkan terserah pengurus mau diapakan yang jelas untuk keperluan pembebasan lahan. Mempermudah wakif, jadi yang menjualkan pengurus saja. ${ }^{28}$

Penyataan di atas menjelaskan bahwa panitia-pengurus Masjid At-Taqwa memberikan kemudahan bagi wakif untuk berwakaf.Wakif bisa mewakafkan uang baik dalam bentuk rupiah maupun selain rupiah, aset, tanah, dan emas.Para panitia/ pengurus menerima semua itu. Kemudian panitia atau pengurus akan memfasilitasinya dengan menjual atau menyewakannya yang akan dikelola atau dipergunakan untuk perluasan masjid tersebut. Hal ini memang membutuhkan proses khusus. Harta benda yang diwakafkan oleh wakif baik berupa uang rupiah atau selain rupiah dan selain uang nantinya akan diuangkan dalam bentuk rupiah juga. Hal ini kembali ke tujuan awal yakni untuk perluasan masjid yang harus

\footnotetext{
${ }^{27}$ Dokumen Masjid At-Taqwa Kota Batu.

28 Tsalis Rifa'i, wawancara, (Malang, 7 April 2016)
} 
membebaskan lahan seluas $1319 \mathrm{~m}^{2}$ dengan harga permeternya Rp. 2.000.000,-. Setiap wakif yang mewakafkan hartanyaakan mendapatkan kuitansi dan beberapa hari kemudian wakif akan diberikan sertifikat wakaf uang sebagai bukti.

Panitia Wakaf uang akan mengumumkan para wakif yang berwakaf dan berapa jumlah wakafnya serta jumlah wakaf uang keseluruhan yang diterima di mading masjid secara periodik. Resume wakaf uang per 12 Mei 2016 terdapat 463 wakif dengan jumlah uang sebesar Rp. 1. 941.576.515,-. Jumlah wakaf uang tersebut belum memenuhi target dari panitia yakni sebesar Rp. 2.638.000.000,- (1319 $\mathrm{m}^{2}$ X Rp. 2.000.000,-). Program wakaf uang masih dijalankan guna memenuhi target tersebut. Setelah target tersebut terpenuhi, panitia wakaf uang masjid At-Taqwa Kota Batu akan mengelolanya. Wakaf uang tersebut dikelola untuk perluasan tahap II Masjid At-Taqwa kota Batu dengan membebaskan lahan seluas 1319 $\mathrm{m}^{2}$ yang berada di jl. Welirang No. 5 Kota Batu (belakang masjid At-Taqwa Kota Batu).

\section{Pengelolaan Wakaf Uang di Masjid Sabilillah Kota Malang}

Pengelolaan wakaf uang yang ada di Masjid Sabilillah Kota Malang diserahkan atau dikelola Koperasi Masjid Sabilillah. Meskipun di Masjid Sabilillah terdapat LAZIS (Lembaga Amal Zakat Infaq dan Shadaqah) yang mengelola wakaf juga, akan tetapi khusus untuk wakaf uang diserahkan atau dikelola oleh Koperasi Masjid Sabilillah. Hal tersebut dilakukan karena agar lebih terfokus pada pengelolaan keuangan yang mensejahterakan umat. Sistem pengelolaan wakaf uang yang ada di masjid Sabilillah dimodel seperti koperasi simpan pinjam, namun dikelola secara syariah. Untuk pengumpulan dana wakaf uang tersebut, para pengurus koperasi telah memberlakukan prosedur perkoperasian. Yakni setiap orang yang akan melaksanakan wakaf uang harus menjadi anggota koperasi masjid Sabilillah terdahulu. Sampai saat ini jumlah anggota koperasi masjid Sabilillah sebanyak 1810 orang. Untuk menjadi anggota koperasi masjid Sabilillah, harus mengisi formulir pendaftaran terlebih dahulu, kemudian terdapat biaya simpanan wajib sebesar Rp. 5.000,- , simpanan pokok Rp. 50.000,- , biaya administrasi Rp. 10.000,- dan biaya wakaf uangnya Rp. 10.000,- jika ditotal jumlah biaya pendaftaran sekaligus wakaf uang permulaan adalah Rp. 75.000,-. Biaya tersebut dibayar awal menjadi anggota saja, untuk selanjutnya jika ingin melakukan wakaf uang dalam jumlah uang berapapun akan diterima oleh koperasi masjid Sabilillah Kota Malang.

Wakaf uang yang terkumpul tersebut kemudian dikelola untuk kesejahteraan umat.Dalam mensejahterakan umat, wakaf uang tersebut dimanfaatkan untuk simpan pinjam oleh anggota koperasi masjid Sabilillah, untuk bisnis pujasera (food court atau pusat makanan) masjid Sabilillah, membantu mengentaskan kemiskinan dan lain sebagainya.Terdapat prosedur yang ditentukan oleh pengurus koperasi masjid Sabilillah dalam melakukan simpan pinjam kepada masyarakat.Untuk bisa meminjam uang di koperasi masjid Sabilillah harus terlebih dahulu menjadi anggota seperti halnya prosedur orang yang ingin berwakaf uang di atas. Untuk bisa pinjam harus menjadi anggota koperasi setidaknya selama 1 tahun. Untuk peminjam yang menjadi anggota di tahun pertama pengurus memberlakukan kebijakan bahwa hanya bisa meminjam sebesar Rp. 2.000.000,-- Sedangkan untuk anggota lama bisa meminjam lebih dari Rp. 2.000.000,--

Sedangkan untuk pengembalian pinjaman tersebut dilakukan secara berangsur selama 10 bulan. Dalam mengangsur biaya pinjaman tersebut, seorang peminjam harus membayar wakaf uang sebesar $0,5 \%$ dari jumlah pinjaman. Misalnya, si A pinjam uang sebesar Rp. 1.000.000,- maka wakaf uangnya 0,5\% dari Rp. 1.000.000,- tersebut yakni sebesar Rp.5000,-. Pembayaran wakaf uang uang tersebut bisa dilakukan sekali pada bulan pertama angsuran.Disinilah letak penggalangan wakaf uang yang dilakukan oleh koperasi masjid Sabilillah dengan sepengetahuan peminjam tersebut. Sistem simpan pinjam yang dijalankan oleh koperasi masjid Sabilillah guna mengelola wakaf uang tersebut telah mengeluarkan biaya 
sebesar 500 juta perbulannya bahkan lebih dengan uang modal yang ada sebesar 2,5 milyar rupiah. dari uang pinjaman tersebut koperasi masjid Sabilillah mendapat wakaf uang sebesar Rp. 2.500.000,- perbulannya dari hasil $0,5 \%$ biaya pinjaman tersebut. Hal tersebut sangat menguntungkan bagi koperasi masjid Sabilillah yang mempunyai misi untuk mensejahterakan umat lebih banyak lagi. Seperti yang dinyatakan oleh pengurus Koperasi Masjid Sabilillah Heru Pratikno sebagai berikut.

Dalam sebulan, koperasi mengeluarkan uang pinjaman sebesar 500 juta. 0,5\% dari 500 juta itu dapat uang wakaf sebesar 2,5 juta. Uang sebesar itu memang dikeluarkan untuk simpan pinjam, kadang lebih.uang modal yang ada yakni sebesar 2,5 milyar. Uang 2,5 juta yang didapat tersebut dari hasil perputaran mengeluarkan. Itu belum dari hasil anggota baru, terkadang orang BPJS itu juga menggunakan koperasi masjid Sabilillah, jadi banyak anggota baru.Keuntungan yang didapat tahun lalu sebesar 90 juta. ${ }^{29}$

Selain untuk simpan pinjam, wakaf uang yang ada di Koperasi Masjid Sabilillah juga digunakan dalam pembangunan pujasera masjid Sabilillah sebesar 40 juta.Pujasera yang dibangun tersebut disewakan kepada anggota koperasi masjid Sabilillah dengan biaya sewa tempat dan gerobak sebesar 300 ribu rupiah perbulan.Keuntungan dari hasil sewa tersebut kemudian digunakan untuk biaya listrik masjid Sabilillah dan juga diputar kembali untuk kesejahteraan umat.

Koperasi masjid Sabilillah memilih untuk mengelola sendiri keuangan yang didapat tersebut dan tidak disimpan di Lembaga Keuangan Syari'ah Penerima Wakaf Uang (LKSPWU) seperti yang dijelaskan dalam pasal 28 Undang-Undang Nomor 41 Tahun 2004. Karena menurut yang disampaikan oleh informan dalam ini adalah pengurus koperasi masjid Sabilillah, jika uang dari wakaf tersebut disimpan di bank maka pengelola tidak akan bermanfaat bahkan akan mengalami kerugian karena adanya bunga tersebut. Koperasi masjid Sabilillah juga tidak menyediakan sertifikat wakaf uang dalam pengelolaannya.Hal ini dikarenakan sistem pengumpulan uang wakaf tersebut masih sederhana dan bisa dibilang masih "recehan". Jika terdapat sertifikatkan menambah biaya lagi dan tidak seimbang dengan uang wakaf yang diterima. Meskipun tidak ada sertifikan wakaf uang, koperasi masjid Sabilillah tetap menyediakan bukti wakaf uang dengan kuitansi.

\section{Perbandingan Pengelolaan Wakaf Uang di Masjid At-Taqwa Kota Batu dan Masjid Sabilillah Kota Malang}

Masjid At-Taqwa Kota Batu dan Masjid Sabilillah Kota Malang memiliki cara masingmasing dalam proses pengelolaan wakaf uang. Masing- masing cara pengelolaan wakaf uang yang dilakukan di kedua masjid tersebut tentu memiliki persamaan dan perbedaan. Berikut dijelaskan dan dianalisis persamaan dan perbedaan pengelolaan wakaf uang di Masjid AtTaqwa Kota Batu dan Masjid Sabilillah Kota Malang. Terdapat beberapa hal persamaan maupun perbedaan dari Masjid At-Taqwa Kota Batu dan Masjid Sabilillah Kota Malang dilihat dari enam aspek. Pertama, dari seri peruntukan atau kegunaan wakaf uang dari kedua masjid tersebut beda dalam mengelola. Di Masjid At-Taqwa Kota Batu dikelola Untuk pembebasan lahan seluas $1319 \mathrm{~m}^{2}$ dengan harga permeter sebesar Rp.2.000.000,- sehingga totalnya Rp.2.638.000.000,- yang digunakan untuk perluasan tahap II Masjid At-Taqwa Kota Batu. Sedangkan wakaf uang di Masjid Sabilillah Kota Malang dikelola untuk simpan pinjam anggota Koperasi Masjid Sabilillah Kota Malang. Kedua, dari segi tim pengelola wakaf uang. Di Masjid At-Taqwa Kota Batu Pengelolaan wakaf uang di kelola oleh panitia khusus yang dibentuk oleh pengurus Masjid At-Taqwa Kota Batu. Sedangkan di Masjid Sabilillah Kota

\footnotetext{
${ }^{29}$ Heru Pratikno, wawancara, (Malang, 12 April 2016)
} 
Malang Pengelolaan wakaf uang dikelola oleh Koperasi Masjid Sabilillah Kota Malang. Ketiga, dari segi instrumen wakaf uang.instrumen wakaf uang yang digunakan di Masjid AtTaqwa Kota Batu yakni uang serta menerima barang selain uang misal tanah dan emas. Sedangkan Instrument wakaf uang yang digunakan di Masjid Sabilillah Kota Malang hanya dengan uang.

Keempat, dari segi batasan wakaf uang. Untuk aspek ini dari Masjid At-Taqwa Kota Batu dan Masjid Sabilillah Kota Malang sama-sama tidak memberikan batasan wakaf uang bagi wakif. Kelima, dari segi Lembaga Keuangan Syariah.Masjid At-Taqwa Kota Batu menggunakan LKS sebagai tempat penyimpanan harta wakaf uang yakni Bank Mandiri Syariah dan BNI Syariah. Sedangkan Masjid Sabilillah Kota Malang tidak Menggunakan LKS sebagai tempat penyimpanan harta wakaf uang.Harta wakaf uang disimpan dan dikelola langsung oleh Koperasi Masjid Sabilillah. Keenam, dari segi sertifikat wakaf uang.Masjid AtTaqwa Mengeluarkan Sertifikat Wakaf uang sebagai bukti untuk wakif yang telah memberikan wakaf uang.Sedangkan Masjid At-Taqwa Mengeluarkan Sertifikat Wakaf uang sebagai bukti untuk wakif yang telah memberikan wakaf uang.

Persamaan dan perbedaan dalam pengelolaan wakaf uang di Masjid At-Taqwa Kota Batu dan Masjid Sabilillah Kota Malang telah dijelaskan di atas. Adapun persamaan dan perbedaan pengelolaan wakaf uang tersebut termuat dalam tabel 1.

Tabel 1. Perbandingan Pengalolaan Wakaf Uang di Masjid at-Taqwa dan Masjid Sabilillah

\begin{tabular}{|c|c|c|c|}
\hline NO & ASPEK & $\begin{array}{l}\text { MASJID AT-TAQWA } \\
\text { KOTA BATU }\end{array}$ & $\begin{array}{c}\text { MASJJID } \\
\text { SABILILLAH KOTA } \\
\text { MALANG }\end{array}$ \\
\hline 1. & $\begin{array}{l}\text { Peruntukan } \\
\text { Wakaf Uang }\end{array}$ & $\begin{array}{l}\text { Untuk pembebasan lahan seluas } \\
1319 \mathrm{~m}^{2} \text { dengan harga permeter } \\
\text { sebesar Rp.2.000.000,- sehingga } \\
\text { totalnya Rp.2.638.000.000,- yang } \\
\text { digunakan untuk perluasan tahap } \\
\text { II Masjid At-Taqwa Kota Batu. }\end{array}$ & $\begin{array}{l}\text { Untuk mensejahterakan umat } \\
\text { dengan memutar uang dari } \\
\text { wakaf uang tersebut dengan } \\
\text { cara simpan pinjam. }\end{array}$ \\
\hline 2. & Pengelola & $\begin{array}{l}\text { Pengelolaan wakaf uang di kelola } \\
\text { oleh panitia khusus yang } \\
\text { dibentuk oleh pengurus Masjid } \\
\text { At-Taqwa Kota Batu }\end{array}$ & $\begin{array}{l}\text { Pengelolaan wakaf uang } \\
\text { dikelola oleh Koperasi Masjid } \\
\text { Sabilillah Kota Malang }\end{array}$ \\
\hline 3. & $\begin{array}{l}\text { Instrumen } \\
\text { Wakaf Uang }\end{array}$ & $\begin{array}{l}\text { instrumen wakaf yang digunakan } \\
\text { yakni uang serta menerima } \\
\text { barang selain uang misal tanah } \\
\text { dan emas. }\end{array}$ & $\begin{array}{lcr}\text { Instrument } & \begin{array}{l}\text { wakaf } \\
\text { digunakan }\end{array} & \begin{array}{r}\text { yang } \\
\text { hengan }\end{array} \\
\text { uang. } & & \end{array}$ \\
\hline 4. & $\begin{array}{l}\text { Batasan } \text { Wakaf } \\
\text { Uang }\end{array}$ & $\begin{array}{l}\text { Tidak ada batasan bagi wakif } \\
\text { untuk memberikan wakaf uang }\end{array}$ & $\begin{array}{l}\text { Tidak ada batasan bagi wakif } \\
\text { untuk memberikan wakaf } \\
\text { uang }\end{array}$ \\
\hline 5 . & $\begin{array}{l}\text { Lembaga } \\
\text { Keuangan } \\
\text { Syariah }\end{array}$ & $\begin{array}{l}\text { Masjid At-Taqwa Kota Batu } \\
\text { menggunakan LKS sebagai } \\
\text { tempat penyimpanan harta wakaf } \\
\text { uang yakni Bank Mandiri Syariah } \\
\text { dan Bank BNI Syariah }\end{array}$ & $\begin{array}{l}\text { Masjid Sabilillah Kota Malang } \\
\text { tidak Menggunakan LKS } \\
\text { sebagai tempat penyimpanan } \\
\text { harta wakaf uang. Harta wakaf } \\
\text { uang disimpan dan dikelola } \\
\text { langsung oleh Koperasi } \\
\text { Masjid Sabilillah. }\end{array}$ \\
\hline 6. & Sertifikat Wakaf & Masjid At-Taqwa Mengeluarkan & Masjid Sabilillah Kota Malang \\
\hline
\end{tabular}




$\begin{array}{lll}\text { Sertifikat Wakaf uang sebagai } & \text { tidak memberikan Sertifikat } \\ \text { bukti untuk wakif yang telah } & \text { wakaf uang, akan tetapi } \\ \text { memberikan wakaf uang } & \text { memberikan kuitansi sebagai } \\ & \text { bukti untuk wakif yang telah } \\ & \text { memberikan wakaf uang. }\end{array}$

Tabel tersebut telah menunjukkan bahwa terdapat persamaan dalam pengelolaan wakaf uang yakni sama-sama tidak ada batasan bagi wakif untuk mewakafkan hartanya dan juga instrumen yang digunakan juga sama. Hanya saja di Masjid At-Taqwa Kota Batu memberikan keringanan dan menerima segala bentuk harta selain uang. Selain persamaan tersebut Masjid At-Taqwa Kota Batu dan Masjid Sabilillah terdapat perbedaan dalam pengelolaannya yakni dari aspek tim pengelola, peruntukan wakaf uang, Lembaga Keuangan Syariah dan dari segi Sertifikat Wakaf uang.

\section{Pengelolaan Wakaf Uang di Masjid At-Taqwa Kota Batu Menurut Pasal 28-30 Undang- Undang Nomor 41 Tahun 2004 Tentang Wakaf}

Pada pembahasan ini dijabarkan mengenai pengelolaan wakaf uang di Masjid At-Taqwa Kota Batu ditinjau dari Undang-Undang Nomor 41 Tahun 2004 tentang wakaf. Tiga pasal yang digunakan adalah pasal 28, 29, dan 30. Aturan yang termuat dalam pasal 28 Undang Undang Nomor 41 Tahun 2004 Tentang Wakaf yakni sebagai berikut:

Wakif dapat mewakafkan benda bergerak berupa uang melalui Lembaga Keuangan Syariah yang ditunjuk oleh Menteri. ${ }^{30}$

Pengurus atau panitia wakaf uang di Masjid At-Taqwa Kota Batu dalam pengelolaannya mempermudah masyarakat atau wakif yang ingin berwakaf. Seorang wakif bisa melakukan wakaf uang dengan tunai datang langsung ke masjid atau bisa juga transfer ke Bank Mandiri Syariah atas nama Masjid At-Taqwa Kota Batu dengan nomor rekening 4443339995 atau ke BNI Syariah atas nama Masjid At-Taqwa Kota Batu dengan nomor rekening 3415923755. Selain wakaf uang dengan menggunakan instrumen uang, panitia wakaf uang Masjid AtTaqwa Kota Batu juga menerima harta wakaf selain uang. Harta tersebut bisa berupa tanah atau emas. Tanah atau emas tersebut kemudian dikelola oleh panitia untuk dijual atau disewakan yang nantinya akan dipergunakan untuk perluasan tahap II Masjid At-Taqwa Kota batu.

Panitia atau pengurus Masjid At-Taqwa Kota Batu memutuskan untuk menerima wakaf selain uang. Hal tersebut karena panitia/pengurus ingin mempermudah wakif dalam beribadah khususnya wakaf tersebut. Mereka memfasilitasi wakif untuk menjual atau menyewakan barang non uang tersebut. Semua harta benda wakaf tersebut dikelola sebaik mungkin guna perluasan tahap II Masjid At-Taqwa Kota Batu. Berdasaran pasal 28 Undang-Undang Nomor 41 Tahun 2004 yang telah dipaparan di atas, bahwa seorang wakif mewakafkan hartanya berupa uang melalui Lembaga Keuangan Syariah yang di tunjuk Menteri. Hal tersebut diterapkan dalam pengelolaan wakaf uang di Masjid At-Taqwa Kota Batu.Wakif yang berwakaf di Masjid At-Taqwa Kota Batu kebanyakan menggunakan uang karena uang merupakan barang yang fleksibel. Namun, panitia wakaf uang juga tidak menolak adanya wakaf berupa selain uang selagi dipergunakan untuk perluasan tahap II Masjid At-Taqwa Kota Batu.

Kemudian dalam pemerimaan wakaf uang, wakif bisa mewakafkan uangnya secara tunai di Masjid At-Taqwa Kota Batu dan bisa melalui Bank Mandiri Syariah dan BNI Syariah yang merupakan Lembaga Keuangan Syariah yang ditunjuk oleh Menteri. Selanjutnya untuk

\footnotetext{
${ }^{30}$ Undang-Undang Nomor 41 Tahun 2004, Pasal 28
} 
aturan yang termuat dalam pasal 29 Undang Undang Nomor 41 Tahun 2004 Tentang Wakaf yakni sebagai berikut: (1) Wakaf benda bergerak berupa uang sebagaimana dimaksud dalam pasal 28 dilaksanakan oleh wakif dengan pernyataan kehendak wakif yang dilakukan secara tertulis; (2) Wakaf benda bergerak berupa uang sebagaimana dimaksud pada ayat (1) diterbitkan dalam bentuk sertifikat uang; dan (3) Sertifikat wakaf uang sebagaimana dimaksud pada ayat (2) diterbitkan dan disampaikan oleh Lembaga Keuangan Syariah kepada wakif dan nadzir sebagai bukti penyerahan harta benda wakaf. ${ }^{31}$

Wakif yang mewakafkan hartanya di Masjid At-Taqwa Kota Batu tersebut semua karena kehendaknya sendiri tanpa ada paksaan di dalamnya.Panitia hanya mensosialisasikan program gerakan wakaf uang tersebut dengan banner dan brosur. Selanjutnya siapapun yang ingin berwakaf bisa datang langsung ke Masjid At-Taqwa Kota Batu dengan mengisi formulir atau transfer ke Bank Mandiri Syariah atau ke BNI Syariah dengan nomor reening atas nama Masjid At-Taqwa Kota Batu. Setelah wakif mewakafkan hartanya ke panitia atau pengurus Masjid At-Taqwa Kota Batu, mereka akan mendapatkan kuitansi dan beberapa hari kemudian akan diberikan sertifikat wakaf uang oleh panitia/ pengurus Masjid At-taqwa Kota Batu.

Berdasarkan isi pasal 29 Undang-Undang Nomor 41 Tahun 2004 dan juga keterangan di lapangan mengenai pengelolaan wakaf uang di Masjid At-Taqwa Kota Batu, terdapat dua ayat yang diterapkan yakni ayat 1 dan 2. Bahwasanya wakif mawakafkan uang/hartanya di Masjid At-Taqwa Kota Batu dengan kehendak sendiri secara tertulis. Setelah menyerahan uang/harta wakafnya secara tunai maupun melalui Lembaga Keuangan Syariah yakni Bank Mandiri Syariah atau BNI Syariah, wakif tersebut akan mendapatkan sertifikat wakaf uang. Mengenai pihak yang menerbitkan sertifikat wakaf uang, Masjid At-Taqwa Kota Batu tidak menerapkan ayat 3 yang menyebutkan bahwa Lembaga Keuangan Syariah yang menerbitan Sertifikat wakaf uang bagi wakif dan nadzir. Sertifikat wakaf uang tersebut diterbitkan dan disampaikan oleh pengurus Masjid At-Taqwa Kota Batu.

Kemudian aturan yang termuat dalam pasal 30 Undang Undang Nomor 41 Tahun 2004 Tentang Wakaf yakni sebagai berikut:

Lembaga Keuangan Syariah atas nama Nadzir mendaftarkan harta benda wakaf berupa uang kepada Menteri selambat-lambatnya 7(tujuh) hari kerja sejak diterbitkannya Sertifikat Wakaf Uang. ${ }^{32}$

Pada pengelolaan wakaf uang di Masjid At-taqwa Kota Batu, yang mengeluarkan sertifikat wakaf uang adalah panitia atau pengurus Masjid At-Taqwa Kota Batu selaku pengelola wakaf uang tersebut.Bank Mandiri Syariah dan BNI Syariah yang merupakan bagian dari Lembaga Keuangan Syariah hanya sebagai tempat penyimpanan uang tersebut.dan tidak ada pelaporan kepada Menteri. Berdasarkan keterangan di atas, isi dari pasal 30 Undang-Undang Nomor 41 Tahun 2004 tersebut merupakan tugas dari LKS-PWU dalam mendaftarkan harta wakaf uang kepada Menteri setelah diterbitkannya sertifikat wakaf uang. Menurut analisis penulis, posisi Masjid At-Taqwa Kota Batu adalah nadzir yang mengelola wakaf uang. Sedangkan untuk pelaporan harta wakaf uang kepada Menteri merupakan tugas dari LKS-PWU tersebut. Sehingga pasal 30 Undang-Undang Nomor 41 Tahun 2004 tersebut tidak diterapkan di Masjid At-Taqwa Kota Batu.

\section{Pengelolaan Wakaf Uang di Masjid Sabilillah Kota Malang Menurut Pasal 28-30 Undang-Undang Nomor 41 Tahun 2004 Tentang Wakaf}

Pada bagian ini, analisis dilakukan dengan menggunakan tiga pasal dalam UndangUndang Nomor 41 Tahun 2004 yang membahas tentang wakaf uang. Tiga pasal itu adalah pasal 28,29, dan 30. untuk menganalisis pengelolaan wakaf uang di Masjid Sabilillah Kota

\footnotetext{
${ }^{31}$ Undang-Undang Nomor 41 Tahun 2004, Pasal 29.

${ }^{32}$ Undang-Undang Nomor 41 Tahun 2004, Pasal 30.
} 
Malang. Aturan yang termuat dalam pasal 28 Undang Undang Nomor 41 Tahun 2004 Tentang Wakaf yakni sebagai berikut:

\section{Wakif dapat mewakafkan benda bergerak berupa uang melalui Lembaga Keuangan Syariah yang ditunjuk oleh Menteri. ${ }^{33}$}

Seorang wakif yang melakukan wakaf uang di Masjid Sabilillah Kota Malang menggunakan instrumen uang. Uang merupakan benda bergerak yang fleksibel dan hampir semua orang dapat memilikinya.Wakif bisa menunaikan wakaf uang tersebut secara langsung atau tunai melalui Koperasi Masjid Sabilillah yang merupakan pengelola wakaf uang di Masjid Sabilillah.

Berdasarkan keterangan di atas, Masjid Sabilillah Kota Malang telah menerapkan sebagian isi pasal 28 tersebut yakni dengan menggunakan instrumen uang dalam berwakaf uang. Karena uang dianggap sebagai benda bergerak yang sangat fleksibel yang hampir semua orang bisa mendapatkan atau memilikinya. Selanjutnya Koperasi Masjid Sabilillah memutuskan untuk tidak menerapkan lanjutan isi pasal 28 tersebut yang menyatakan bahwa wakaf uang yang dilakukan wakif melalui Lembaga Keuangan Syariah yang ditunjuk Menteri. Hal tersebut tidak diterapkan karena akan lebih menguntungkan Lembaga Keuangan Syariah yang merupakan suatu instansi bank. Pengurus Koperasi beranggapan bahwa akan lebih efisien dan manfaat jika wakaf uang tersebut langsung melalui Koperasi Masjid Sabilillah Kota Malang selaku pengelola wakaf uang di Masjid Sabilillah Kota Malang.

Selanjutnya untuk aturan yang termuat dalam pasal 29 Undang Undang Nomor 41 Tahun 2004 Tentang Wakaf yakni sebagai berikut: (1) Wakaf benda bergerak berupa uang sebagaimana dimaksud dalam pasal 28 dilaksanakan oleh wakif dengan pernyataan kehendak wakif yang dilakukan secara tertulis; (2) Wakaf benda bergerak berupa uang sebagaimana dimaksud pada ayat (1) diterbitkan dalam bentuk sertifikat uang; (3) Sertifikat wakaf uang sebagaimana dimaksud pada ayat (2) diterbitkan dan disampaikan oleh Lembaga Keuangan Syariah kepada wakif dan nadzir sebagai bukti penyerahan harta benda wakaf. ${ }^{34}$ Seorang wakif yang melakukan wakaf uang di Koperasi Masjid Sabilillah atas kehendak sendiri dan tanpa paksaan. Meskipun dalam ketentuan simpan pinjam terdapat kewajiban untuk membayar wakaf uang, akan tetapi jumlah wakaf uang yang ditentukan tidak memberatkan wakif dan wakif pun tidak keberatan. Wakif yang mewakafkan uangnya tidak mendapatkan sertifikat wakaf uang yang diterbitkan oleh LKS yang ditunjuk oleh Menteri.Karena wakaf uang di Masjid Sabilillah tidak dikelola maupun disimpan di LKS tersebut, namun disimpan dan dikelola oleh Koperasi Masjid Sabilillah.Kemudian untuk bukti bahwa wakif melakukan wakaf uang, Koperasi Masjid Sabilillah menyediakan Kuitansi sebagai bukti.

Berdasarkan keterangan di atas, Masjid Sabilillah telah menerapkan ayat 1 pasal 29 Undang-Undang Nomor 41 Tahun 2004.Hal tersebut ditunjukkan bahwa wakif yang mewakafkan harta/uangnya di Koperasi Masjid Sabilillah Kota Malang atas kehendak wakif yang dilakukan secara tertulis.Sedangkan untuk ayat 2 dan 3 pasal 29, pengurus Koperasi Masjid Sabilillah memutuskan untuk tidak menerapkannya. Hal tersebut dilakukan karena pengurus Koperasi Masjid Sabilillah Kota Malang beranggapan bahwa akan menambah biaya lebih jika mengeluarkan sertifikat wakaf uang kepada wakif yang tidak semua mewakafkan harta/uangnya dalam jumlah yang besar.

Akan lebih efisien jika hanya mengeluarkan kuitansi sebagai bukti wakaf uang tersebut. Dengan pengeluaran yang tidak terlalu banyak kuitansi tersebut sudah bisa menjadi bukti

\footnotetext{
${ }^{33}$ Undang-Undang Nomor 41 Tahun 2004, Pasal 28

${ }^{34}$ Undang-Undang Nomor 41 Tahun 2004, Pasal 29.
} 
wakaf uang di Masjid Sabilillah Kota Malang. Kemudian aturan yang termuat dalam pasal 30 Undang Undang Nomor 41 Tahun 2004 Tentang Wakaf yakni sebagai berikut:

Lembaga Keuangan Syariah atas nama Nadzir mendaftarkan harta benda wakaf berupa uang kepada Menteri selambat-lambatnya 7(tujuh) hari kerja sejak diterbitkannya Sertifikat Wakaf Uang. ${ }^{35}$

Wakaf uang di Masjid Sabilillah Kota Malang telah dikelola oleh Koperasi Masjid Sabilillah. Koperasi Masjid Sabilillah menyimpan dan mengelola wakaf uang tersebut dengan cara simpan pinjam. Cara tersebut digunakan untuk mensejahterakan umat khususnya dalam segi ekonomi umat. Berdasarkan keterangan diatas, Masjid Sabilillah Kota Malang memilih untuk tidak menerapkan pasal 30 tersebut.Hal tersebut karena Koperasi Masjid Sabilillah Kota Malang bukan merupakan Lembaga Keuangan Syariah yang didaftarkan Menteri untuk mendaftarkan harta benda wakaf uang sebagaimana yang tercantum dalam isi pasal 30 Undang Undang Nomor 41 Tahun 2004. Jadi, menurut pasal 28, 29, dan 30 Undang-Undang Nomor 41 Tahun 2004 terdapat beberapa hal yang diterapkan maupun tidak dalam pengelolaan wakaf uang di Masjid At-Taqwa Kota Batu dan Masjid Sabilillah Kota Malang. Hal tersebut terjadi karena didasari oleh latar belakang pemikiran dan konsep yang dibangun di Masjid At-Taqwa Kota Batu dan Masjid Sabilillah Kota Malang.

\section{Kesimpulan}

Perbandingan pengelolaan wakaf uang dalam artikel ini untuk mengidentifikasi persamaan dan perbedaan dalam pengelolaan wakaf uang di Masjid At-Taqwa Kota Batu dan Masjid Sabilillah Kota Malang. Bukan sebagai pembanding untuk merendahan atau meninggikan dari salah satu masjid tersebut. Terdapat beberapa persamaan maupun perbedaan pengelolaan wakaf uang di Masjid At-Taqwa Kota Batu dan Masjid Sabilillah Kota Malang antara lain: Pertama, dari seri peruntukan atau kegunaan wakaf uang dari kedua masjid tersebut beda dalam mengelola. Kedua, dari segi tim pengelola wakaf uang. Ketiga, dari segi instrumen wakaf uang. Keempat,dari segi batasan wakaf uang. Kelima, dari segi Lembaga Keuangan Syariah. Keenam, dari segi sertifikat wakaf uang. Dari keenam aspek tersebut, hanya pada aspek batasan wakaf uang saja pengelolaan wakaf uang di Masjid At-Taqwa Kota Batu dan Masjid Sabilillah Kota Malang terdapat persamaan. Sedangkan kelima aspek lainnya terdapat perbedaan di kedua Masjid tersebut. Berdasarkan isi pasal 28, 29, dan 30 UndangUndang Nomor 41 Tahun 2004, terdapat beberapa hal yang diterapkan maupun tidak dalam pengelolaan wakaf uang di Masjid At-Taqwa Kota Batu dan Masjid Sabilillah Kota Malang. Hal tersebut terjadi karena didasari oleh perbedaan latar belakang pemikiran dan konsep yang dibangun oleh Masjid At-Taqwa Kota Batu dan Masjid Sabilillah Kota Malang.

\section{Daftar Pustaka :}

Djunaidi, Achmad (et.a.).Pedoman Pengelolaan Wakaf Tunai (Jakarta: Departemen Agama RI, 2007

Faisal, Sanapiah.Format - Format Artikel Sosial, Jakarta: PT. RajaGrafindo Persada, 2005. al-Hafsakī, Alauddin Muhammad bin 'Ali. vol. IV. ad-Dur al-Mukhtār, t.tp.: t.p., t.th. al-Kabisi,Muhammad Abid Abdullah,Hukum Wakaf. terj. Ahrul Sani Fathurrohman (et.al.), Jakarta, IIMaN Press, 2004

Koentjaraningrat. Metode - Metode Artikel Masyarakat,(Jakarta: PT Gramedia Pustaka Utama, 1997.

ibn Mājah.vol. VII. Sunan Ibn Mājah. Kairo: Mauqi` Wizārah al-Auqāf al-Miṣriyyah, t.th.

\footnotetext{
${ }^{35}$ Pasal 30 Undang-Undang Nomor 41 Tahun 2004 tentang Wakaf
} 
Manan,Abdul.Reformasi Hukum Islam di Indonesia, Tinjauan dari Aspek Metodologis, Legalisasi, dan Yurisprudensi. Jakarta: RajaGrafindo Persada, 2006.

Mubarok, Jaih,Wakaf Produktif.Bandung: Simbiosa Rekatama Media, 2008.

ibnu Mūsā, Abdullāh. Waqf an-Nuqūd wa al-Aurāq al-Māliyah, 2005.

ibn Qudāmah, 'Abd ar-Rahmān bin Abū 'Umar.Vol. VI. asy-Syarh al-Kabïr, t.tp.: t.p., t.th.

Supardi dan Amiruddin Teuku. Manajemen Masjid dalam Pembangunan Masyarakat, Optimalisasi, dan Fungsi Masjid. Yogyakarta: UII Press Yogyakarta,2010.

Tim Penyusun. Himpunan Fatwa Majelis Ulama Indonesia. Jakarta: Dirjen Bimas Islam dan Urusan Haji Departemen Agama RI 2003.

at-Turmużi,Muhammad bin 'Isa, vol. V.Sunan at-Turmużì. Kairo: Mauqi' Wizārah alAuqāf al-Mișriyyah, t.th.

Warson,Ahmad.al-Munawwir, Kamus Arab-Indonesia, t.tp.: t.p., 1984.

Wehr,Hans.Arabic-English Dictionary, the Hans Wehr Dictionary of Modern Written Arabic.

Urbana: Spoken language Services, Hans, 1994.

az-Zuhaili,Wahbah. al-Fiqh al-Islāmī wa Adillatuh. Beirut: Dār al-Fikr, t.th.

Undang-Undang Nomor 41 Tahun 2004 tentang Wakaf

Heru Pratikno, wawancara (12 April 2016)

Tsalis Rifa'i, wawancara (7 April 2016) 